\title{
ГЕРМЕНЕВТИКА СКРЫТЫХ ТЕКСТОВ: МИФ, ТИТАНИЗМ И ДОЛГОЖИТЕЛЬСТВО
}

\begin{abstract}
Аннотация. Особенность статьи в том, что в ней герменевтика обращена не к письменному источнику, а к устному, т.е. к народной культуре. Герменевтическое средство, которое преимущественно используется, - понятие генотекста, введенное Джулией Кристевой (Julia Kristeva) с опорой на русскую семиотику. Показано значение герменевтических идей М.М. Бахтина и В.С. Библера. Общее определение культуры принято в формулировке П.С. Гуревича. Освобождение генотекста от оболочки фенотекста раскрыло роль сакральности культуры, титаническую составляющую в самоопределении человека и восхождение к этим началам поведения долгожителей (на примере абхазской популяции, долгие годы изучавшейся автором).
\end{abstract}

Ключевъе слова: философия, герменевтика, генотекст, миф, кинесика, ноги, хтонизм, титаны, долгожители, абхазы.

\section{1. От фенотекста к генотексту (По работам Ю. Кристевой)}

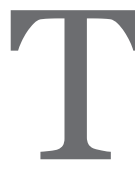
екстами Юлии Кристевой можно восхищаться и аплодировать, если бы не ее склонность к скучным квазиматематическим доказательствам. Она вошла в науку как структуралист с выучкой у Клода Леви-Строса и Роланда Барта. Но осталась верна Зигмунду Фрейду и Жаку Лакану. Причем теории последнего излагала более внятно, чем сам мэтр. Особенно это касается «дозеркальной» стадии человеческой психики. Понятно, что ею принята «доэдиповская» стадия у ребенка (Фрейд и близкие позиции Отто Ранка и Мелани Кляйн). И тогда уже исчезает у нее структура и остается «процесс» и «кризис». Семиотика же стала семанализом, в котором констатируется подавление обществом материнского и женского начал и появление вследствие этого культуры.

Различение генотекста и фенотекста Кристева ввела в самом начале своей научной карьеры. В книге «Семиотика» 1969 г. ${ }^{1}$, затем и в «Революция поэтического языка» 1974 г. $^{2}$ она использовала это

\footnotetext{
${ }^{1}$ Kristeva J. Séméiôtiké: recherches pour une sémanalyse, P.: Edition du Seuil, 1969. (Английский перевод — Desire in Language: A Semiotic Approach to Literature and Art. Oxford: Blackwell, 1980).

2 Kristeva J. La Révolution du langage Poétique: Lavant-garde a la fin du XIXe siècle, Lautréamont et Mallarmé. Paris: Éditions du Seuil, 1974. (Английский перевод - Revolution in Poetic Language, New York: Columbia University Press, 1984).
}

различение, введенное в аппликативной порождающей модели языка советских структуралистов С.К. Шаумян и П.А. Соболевой в начале 1960-х годов $^{3}$. Кристева со сноской на логико-математический подход видит свою задачу в раскрытии «последовательной переформулировки и переплетения языковой сети», которое имеет место в тексте. Сам текст осциллирует между порождающим генотипом и фенотипом ${ }^{4}$. Это довербальный и бессознательный уровень субъекта, означивающий процесс, но не знаковая система. Еще дофразовый уровень, не сводимый к лингвистическим структурам языка. Он «неструктуризован» и «не структуризует». Он бесконечен.

Кристева придала генотексту расширенный антропологический смысл. Он охватил психические состояния до дискурсивных жанров, моделирование тела, отношения ребенка к родителям, экологию и социум, в которых помещена личность. Фенотекст имеет уже социокультурную санкцию. Он останавливает возгонку смыслов генотипа, подчиняя его правилам коммуникации и идеологическим формулам. Фенотип - это конкретные манифестации культуры, коммуникации, факты.

\footnotetext{
3 Шаумян С.К Аппликативная порождающая модель // Словари и энциклопедии на Академике [Электронный ресурс] // http://enc-dic.com/enc_sovet/Applikativnaja-porozhdajuschajamodel-69903.html.

${ }^{4}$ Kristeva J. Séméiôtiké: recherches pour une sémanalyse, P.: Edition du Seuil, 1969. P. 216-217, 224-225.
} 


\section{Герменевтика}

Сама Кристева после блестящих ранних аналитических исследований развивалась как теоретик феминистского движения и талантливый романист. Ее понимание генотипа, скрытого внутри фенотипа, в трудах последователей иногда приводило к оригинальным трактовкам творчества. Я бы отметил прекрасное исследование М.Д. Шекели, применившего семанализ к Бартовской музыкологии ${ }^{5}$.

Удивительно интеллектуальное балансирование Ю. Кристевой. Видно, не случайно она себя во Франции аттестует «иностранкой». Эта позиция обеспечивает ей свободу в обращении с ментальными материками европейской мысли. Примечательно, что выгодность подобной позиции подчеркнуто в Платоновском диалоге «Софист», где идея объективности мышления вложена в уста Чужеземца'

Итак, Кристевой мы обязаны углубленной разработкой концепции генотекста, ставящего герменевтическую проблематику его поисков под наслоениями фенотекста. Речь, следовательно, идет о скрытом тексте. Тексте, а не неком культурном образце. Такой текст должен отличаться свойством культурогенной развертываемости, при которой его сокрытость выступает в виде незавершенности.

К подобному пониманию механизма культуры можно прийти и не структуралистским путем. В мировой культурологической мысли преобладал не семиотический, а семантический путь антропологических поисков смысла. Методология последнего была четко сформулирована П.С. Гуревичем: «Выявление специфики культуры невозможно без антропологических констатаций и без выявления сакрального смысла человеческой деятельности. Следовательно, можно определить культуру как феномен, рожденный незавершенностью, открытостью человеческой природы, развертыванием творческой деятельности человека, направленной на поиск сакрального смысла бытия» (выделено П.С. Гуревичем. - Я.Ч.) ${ }^{7}$. Отнесемся к данному определению стратегически как к указанию на творческую природу человека. Тогда семанализ Кристевой предстанет тактическим техническим приемом, который уже можно всячески корректировать, исходя из особенностей каждой из обсуждаемых ниже проблем.

\footnotetext{
${ }^{5}$ Szekeley M.D. Gesture, Pulsion, Grain: Bartes' Musical Semiology [Электронный ресурc] // // http://www.contempaesthetics. org/newvolume/pages/article.php?articleID $=409$.

${ }^{6}$ Библер В.С. Сократ и Кратос. Энигма-диалог по пяти диалогам Платона [Электронный ресурс] // http://www.bibler.ru/ bis_sokrat.html.

7 Гуревич П.С. Философия культуры. М., 2001. С. 37.
}

\section{2. Путь от Бахтина к энигме Библера}

В интеллектуальной игре Ю. Кристевой есть надежное основание - творчество российского гения Михаила Михайловича Бахтина. В зарубежных отзывах на творчество Кристевой хорошо отслеживаются ходы ее мысли. Но роль М.М. Бахтина явно недооценивается. А ведь это от Бахтина идет подчеркивание тела и бессознательного, которые шире лингвистических рамок и дают человеку игру, удовольствие и желание. Установка Бахтина тоже, впрочем, идущая от Фрейдовской концепции побуждения.

М.М. Бахтину посвящена огромная литература. Если поставить задачу подойти к Бахтину как к герменевту, то тут помощь В.С. Библера оказывается незаменимой.

Конечно, М.М. Бахтин работал с письменным источником, а не устным. Но как работал! Вот мнение В.С. Библера о философии Бахтина. «Человек там, где речь; речь там, где диалог; диалог там, где литература. Во всяком случае, достроенный, бесконечно развитый, глубинно понятый диалог там, где существует - пусть потенциально представления, - художественная литература»; «исследователь-гуманитарий выявляет, актуализирует этот смысл, достраивая любую речь до «произведения художественной литературы»... Вот смысл той переформулировки, в которой литературоведение есть единственное определение единственного дела жизни Бахтина» ${ }^{\text {. }}$

Здесь четко обозначено начало Бахтинской герменевтики. Это не только письменные источники, которые дали классическую герменевтику, но само порождающее устное начало, человеческая речь. Потому-то Бахтин был не согласен с формальной семиотикой. «Семиотика, говорил он, занята преимущественно передачей готового сообщения с помощью готового кода. В живой же речи сообщение, строго говоря, впервые создается в процессе передачи и никакого кода, в сущности, нет»9. Далее у Бахтина: «Контекст потенциально незавершим, код должен быть завершимым. Код - только техническое средство информации, он не имеет познавательного творческого значения. Код - нарочито установленный, умерщвленный творческий контекст» ${ }^{10}$.

И вот, наконец, Бахтинское понимание текста. «...Одновременно каждый текст (как вы-

\footnotetext{
8 Библер В.С. Михаил Михайлович Бахтин, или Поэтика культуры. М., 1991. С. 79-80.

9 Бахтин М.М. Эстетика словесного творчества. М., 1986. С. 371.

10 Там же. С. 372.
} 


\section{Философия и культура 5(65) • 2013}

сказывание) является чем-то индивидуальным, единственным и неповторимым... По отношению к этому моменту все повторимое и воспроизводимое оказывается материалом и средством. Это в какой-то мере выходит за пределы лингвистики и филологии. Этот второй момент (полюс) присущ самому тексту, но раскрывается только в ситуации и в цепи текстов» ${ }^{11}$.

В Бахтинской герменевтике сама жизнь наполнена художественным содержанием, образуя «единство события-бытия». В своей ранней философской работе он писал: «Акт-поступок эстетического видения возвышается над всяким эстетическим бытием - его продуктом - и входит в иной мир, в действительное единство события-бытия, приобщая ему и эстетический мир как момент его ${ }^{12}$. Из этого мировоззрения развернулись все последующие Бахтинские работы.

И наконец, о том, как видел Библер значение художественной формы у Бахтина: «...О чем бы ни писал М.М. Бахтин - о поэтике романов Достоевского, или о творчестве Франсуа Рабле, или - о романе Воспитания, он - одновременно - воспроизводил некое культурное действо (событие), некий особый социум культуры, лежащий в подоснове «профессионального» художественного произведения». «По идее Бахтина, живопись и музыка, архитектура и скульптура (продолжим список - философия и наука...) могут быть поняты как свидетельство жизни человеческого духа лишь тогда, когда они доведены до формы «художественной речи», до «литературы», когда мы ... «дополняем» эту идею до идеи художественного (= литературного) произведения» ${ }^{13}$.

Что же у нас в итоге? В.С. Библер увидел у Бахтина формулировку целостного видения мира и такого же предмета исследования. В своей целостности предмет всегда не познаваем до конца: в нем остается загадка.

Загадке-энигме Библер уделил особое внимание. Охарактеризуем это учение Библера в изложении одного из участников знаменитых семинаров П.Д. Тищенко ${ }^{14}$.

\footnotetext{
11 Там же. С. 299.

12 Бахтин М.М. К философии поступка // Философия и социология науки и техники. Ежегодник. 1984-1985. М., 1986. C. 94 .

13 Библер В.С. Михаил Михайлович Бахтин, или Поэтика культуры. М., 1991. С. 78, 79.

14 Тищенко П. Библер Владимир Соломонович [Электронный ресурс] // http://encyclopaedia.biga.ru/enc/liberal_arts/
}

«Подобного рода загадки (или «энигмы» в терминологии Библера) лежат в «начале» любого логического рассуждения. Они побуждают мысль работать, ориентируют ее в определенном направлении, но не предрешают полученных результатов. Фундаментальная загадочность бытия как парадоксальное начало содержит в себе возможности для практически необозримого многообразия логических решений.

По Библеру, каждая культура имеет свой особый тип загадочности (энигматичности) и свой специфический способ разгадывания (свой тип разума). Например, античная культура загадывает себя в форме упомянутых выше апорий - типа апорий Зенона или апорийных определений бытия и ничто, бытия и движения, единого и многого платоновского диалога Парменид. Разгадать загадочность бытия означает для греческой мысли в буквальном смысле определить, заключить хаос становящегося мира в пределы формы прекрасного эйдоса.

Загадочность средневекового разума, по Библеру, представлена в форме антитез божественного «ничто» и тварного «всего», связанных идеей порождения и причастности. Нечто существует по своей причастности абсолютному субъекту, который в сравнении со «всем» тварным предстает как творящее, но не сотворенное «ничто». Бог - это такое ничто, которое порождает все. Связь нечто и ничто загадочна. Причем эта загадочность лежит в основе осмысления бытия любой вещи. В основе бытия человека эта загадка узнается как вопрос о предопределении человеческой судьбы».

Далее. «В противовес индукции и дедукции философская логика культуры Библера предлагает логику «трансдукции» не обобщения, а общения (диалога) разумов различных культур. Общим основанием всех культур, на котором они могут со-общаться друг с другом и не терять специфики, является специфически загаданное для каждой культуры «бесконечно возможностное бытие». Именно поэтому философская логика конца XX, начала XXI вв. по Библеру предстает логикой парадокса, возможности особого общения различных культурных типов логики, различных культур, разумов и регулятивных идей личности без их «обобщения». Единственные и неповторимые актуализации фундаментальной загадочности бытия (будь то философские, художественные, религиоз-

BIBLER_VLADIMIR_SOLOMONOVICH.html. Я приношу извинения автору за обширное цитирование, но оно лучше всего способствует восприятию и распространению взглядов В.С. Библера. 


\section{Герменевтика}

ные или иные произведения культуры) возникают, по Библеру, в «ответно-вопросительном событии» с другими, столь же уникальными и неповторимыми актуализациями. Их связью оказывается диалог, оформляющий бесконечно возможностное бытие как если бы оно было произведением культуры. В качестве такового можно рассматривать как отдельные произведения (к примеру, философские), так и предельные идеи культур (прежде всего античный, средневековый и новоевропейский разумы».

И наконец, П.Д. Тищенко о философской логике в герменевтике Библера. «Библеровская идея философской логики культуры является творческим переосмыслением идей поэтики культуры М.М. Бахтина. Принципиальное отличие в том, что поэтика в концепции Бахтина предстает как эстетическая категория, определяющая целостность произведений культуры. С бахтинской точки зрения, любая логика имеет частный, абстрактный характер. В философии В.С. Библера поэтика осмысляется как философская логика, которая как целостная форма (произведение культуры) находится в диалогическом отношении к не менее целостному произведению культуры в формах художественного творчества (например, поэзии). Таким образом, между ними нет отношения «части» и «целого», как в концепции Бахтина» ${ }^{15}$.

Свое понимание энигмы Библер развивает в книге о Бахтине в том месте, где он анализирует поэзию А.С. Пушкина. На примере стихотворений поэта Библер показывает, что во многих из них где-то в середине текста появляется непонятная строка. Ее значение можно иногда понять из знакомства с личной жизнью поэта. После такой строки поэтика стихотворения начинает двигаться в новом русле.

\section{3. Личный миф, кинесика и герленевтика юсизи}

Совместный опыт двух герменевтик, Бахтина и Библера, помогает обнаружить энигму у Пушкина, которая оказывается скрытым прототекстом: личным мифом его жизни. Вспомним стихи поэта, ибо ни у кого другого личный миф не был столь сильным побудителем творчества. И поэт это сам чувствовал, когда себя воспринимал статуарно перед величием природы. «Кавказ подо мною». «Я памятник себе воздвиг нерукотворный». Что это как не статуарная поза, замерший жест? Но то, что восчувствовал поэт,

\footnotetext{
15 Там же.
}

мы обыденно показываем на своих фотографиях, остолбенело творя ими личный миф.

Откуда же статуарность, «окаменелость»? Попытаемся раскрыть ее через скрытую герменевтику ног.

В исследовании проблем кинесики (жестов и поз) 1998 г. я отталкивался то того, что руки человека находятся в более «многомерном» пространстве, чем ноги ${ }^{16}$. Движения ног четче ограничены горизонталью или вертикалью. Если руки могут занимать в пространстве до 600 положений, из которых многие могут быть лживыми, маскировочными посланиями, то иное дело ноги. Они реже отклоняются от «честной» функции поддерживания на земле человеческого тела.

В книге 1998 г. был проанализирован большой материал о символике ножных жестов. Выводы состояли в следующем.

«Демонстрационное манипулирование и персонификация природы ( «третье лицо») представляют собой одно явление в плане наделения предметов окружающего мира символическим содержанием, превращения их в контрагента кинесических движений. Мы уже касались этой проблемы в связи с особой ролью земли в кинесике ног. Ни позы, ни жесты не могут обойтись без этих контрагентов. Семантика кинесики не может быть вырвана из материальноприродной среды. Что касается ног, то речь должна идти, прежде всего, о земле и растительности, точнее говоря, о хтонических силах.

Из всего этого следует важное заключение: кинесика не является дериватом вербального языка, у нее свой генезис. Она не может быть диакритическим знаком такого языка. При этом начала этого генезиса находятся в первой сигнальной системе, но развитые уровни связаны с оперативными целями, которые возникают как результат функционирования всех систем человека. Исходно обладая самостоятельным, не зависимым от вербального языка генезисом, кинемы и кинемоморфемы активно выступают не только в сфере коммуникации по типу Я - Он, но и в коммуникации Я - Я (автокоммуникации).

Связь с языком иногда препятствуют познанию сущности кинесики. «При нерасчлененно-совместном их рассмотрении обращают внимание на то, что вербальный язык воздействует на слуховые анализаторы, а кинесика - на зрительные. Поэтому за кинесикой закрепляют только межличностную визуальную коммуникацию, тогда как для вербаль-

\footnotetext{
16 Чеснов Я.В. Лекции по исторической этнологии. М.: Гардарика, 1998. С. 235.
} 


\section{Философия и культура 5(65) • 2013}

ного языка допускают существование внутренней речи. В отношении же кинесики подчеркивание ее интериоризованного внутреннего аспекта может показаться неожиданным. Между тем основная функция кинесики лежит в сфере автокоммуникации. Действительно, все проявления эмоциональноличного отношения к жизни охвачены кинесикой. Не случаен огромный диапазон эмоциональных выражений, свойственных отдельным индивидам. Отметим большую степень непроизвольности этих выражений, их порой досадное выскальзывание изпод контроля сознания.

Что происходит с индивидом в процессе кинесической автокоммуникации? Как отмечает Юрий Лотман, в коммуникации по типу Я - Я наблюдается перестройка самого Я. В нашем случае речь идет о возбуждении или торможении эмоциональных центров человека. Эмоционально-личностное восприятие действительности сопровождается и регулируется проявлениями любви и ненависти, радости и огорчения, внимания и безразличия, участия и незаинтересованности, возмущения и покорности, досады и удовлетворения, хладнокровия и страха, упоения и испуга, удивления и спокойствия, ненависти и гнева, серьезности и иронии. Этот тип информации, который ведет к перестройке воспринимающей системы, был назван Юрием Кнорозовым фасцинацией - такое действие сигнала, при котором ранее принятая информация полностью или частично стирается. Он же отметил раздельность подачи фасцинирующих и собственно информативных сигналов. Особое внимание обращено Кнорозовым на семантическую функцию фасцинации: неясность и многозначность ее действуют как сильнейшее средство. В качестве примера семантической фасцинации приводится искусство, предполагающее выдумку, мнимые события и типы личности. Полисемантизм кинесики как раз и содержит ту образно-эмоциональную информацию, которая воздействует на перестройку личности: позы и жесты могут успокаивать, создавая комфорт или давая разрядку, могут переводить в возбужденное состояние. На этих кинесических механизмах основан эффект аутотренинга в его разных системах» ${ }^{17}$.

«Все это заставляет увидеть в кинесике одну из форм жизнедеятельности человека. Отличительная черта кинесики от других, более четко осознаваемых форм жизнедеятельности, заключается в том, что целесообразность кинесических движений, прежде всего кинем, скрыта от субъекта. Во внешне коммуникативном процессе кинесика участвует лишь частью своих возможностей (кинемоморфемами). Основное ее воздействие - фасцинирующее, направленное на перестройку внутренних процессов организма, на изменение его физиологического и эмоционального состояния (кинемами). Механизм эмоциональных возбуждений уже достаточно изучен - это корковоподкорковые комплексы, в которых главную роль играет новая кора мозга. Этот механизм формирует индивидуальные эмоционально окрашенные мотивации, необходимые для трансформации потребностей во внешне реализуемое целевое поведение. С точки зрения биологических функций организма, кинесика - мощное фасцинирующее средство, задающее ритм. Последний стабилизирует индивида и личность в целом. Кинесика, таким образом, есть форма жизнедеятельности, которая обеспечивает функционирование других, более высоких форм, воздействию которых она подчинена. Отсюда ее определенные связи с языком, который активно влияет на кинесику в направлении превращения ее в один из параллельных кодов ${ }^{18}$.

\section{4. Шаг надеждъ}

Сделать следующий ход в раскрытии смысла поз можно, только наполнив предложенное понятие контрагента жеста категориальным содержанием. В данном случае мы обращаемся к хтонически растительным объектам, как к тому «третьему лицу», ощущение которого необходимо для нормальной жизнедеятельности человека.

«Под контрагентом кинесического движения мы понимаем природный объект, эмоционально выделенный из окружающего мира и фасцинирующе воздействующий на человека. Растительная среда оказывает стабилизирующее влияние на индивидуально биологическую ритмику человека. Она выступает контрагентом многих видов релаксационной кинесики, в том числе и поз сидения.

Понятие контрагента дает основания вернуться к рассмотрению шага Майтрейи. Эта поза свидетельствует о переходе из состояния хтонической наполненности сил к действию. Опущенная ступня в кинесическом смысле - жест, обращенный к земле, иначе - жест, указывающий на контрагента. Земля в этом качестве - контрагент одного из самых высоких уровней, но стоящий ниже Космоса. Сама этимология русского слова «земля» восходит к обозначению низа («ударился оземь»). Здесь скрытый текст, возникший у ис-

17 Там же. С. 239.

18 Там же. С. 240. 


\section{Герменевтика}

токов речи, уже подчеркивал статусный уровень Космоса» ${ }^{19}$.

Шаг Майтрейи основан на общечеловеческом символе космической помощи нуждающимся в этом людям. Выразительность этого кинесического движения исходит из того, что, в сущности, перед нами один из указательных жестов. Последние сыграли огромную роль в развитии неконтактного, символического моделирования действительности и освоения внешнего мира, что привело к возникновению человеческой речи.

Соотнесенность ног с земным и хтоническим уровнем уже выявилась в палеолитических пещерах Франции, где на глинистом полу были обнаружены отпечатки пяток инициируемых юношей. Ноги и в этнографическом материале акцентируют приобщение к сакральному знанию (немецкий глагол «знать» kennen связан с обозначением колена Knie). В мировых религиозно-философских системах жесты ног наполнены смыслом: изображения Христа-Спасителя на некоторых иконах с ногой, выступающей за рамку, опущенная к земле нога будущего Будды Майтрейи, сидящего в цветке лотоса. Это знаки надежды для человеческого существования.

\section{5. Почему «в ногах нет правдъц?}

В одной из первых публикаций К. Леви-Строса по-русски в «Вопросах философии» уже упоминалась мифологема ног ${ }^{20}$. Но там речь шла о структуре мышления, и для антрополога в этом указании на ноги не было ничего неожиданного. Мне уже приходилось думать о таких фактах, как древнерусский обряд разувания жениха невестой ${ }^{21}$, сватании у якутов, когда парень перекидывает через жилище невесты торбаса (меховая обувь), широко распространенное на Кавказе дарение невестой новым родственникам связанных ею носков и т.п.

В 1980-е годы пошло обильное накопление собственных культурно-антропологических данных на Кавказе. Этому способствовала доступность трудов Леви-Строса благодаря переводам всех его основных сочинений. Непоследнюю роль играло положение 3. Фрейда о подглядывании ног взамен скрытых гениталий ${ }^{22}$. Выявилось отношение ног к хтоническому

\footnotetext{
19 Там же. С. 246-247.

20 Леви-Строс К. Структура мифов // Вопросы философии. 1970. № 7. С. 154-164.

21 Чулков М. Абевегеда русских суеверий. М., 1776. С. 56.

22 Фрейд 3. По ту сторону принципа наслаждений. Я и Оно // Фрейд 3. Избранные труды. Л., 1969. Т. 1. С. 31.
}

миру, где размещены зародыши жизней. У абхазов этот смысл передается через след: «Чтобы твой след не пропал», т.е. чтобы продолжалось потомство человека. Иногда произносят тост «За следы такогото». В присутствии гостя не абхаза поясняют: «За его семью». У них же есть молитва, обращенная к «золотым ступням Бога». Армянская молитва к солнцу, где его просят не снимать ступню с лица молящегося, оказалась известна К.-Г. Юнгу ${ }^{23}$. Эти речения с непонятным происхождением раскрыты мной через концепцию «эмбриональной цепи», которая восходит к хтоническим представлениям о выходе из недр земли «эмбриональной цепи». В ней пол ребенка чередуется. Эта концепция объяснила странные приметы. Так, у абазин и чеченцев я зафиксировал верование, что если ребенок лет до пяти согнется и станет смотреть между ног назад, то это к гостям. Это ребенок «видит» приход следующего за ним эмбриона. А скрытый текст гостя - это его «эмбриональная» функция: гость приносит благо, а среди блага первейшее дети. Полноценная модель человека в чеченском понимании предполагает крепкие связи с предками и потомками. Это состояние выражается фразой «От головы до ног наполненный».

Скрытый текст ног оказался организован ризомно. Обратимся к хромоте - ритуальной одноногости. В кавказской повседневности хромоногие мужчины в старину становились кузнецами. Таким был великий балкарский поэт Кязым Мечиев, кузница которого была одновременно центром интеллектуальной жизни народа. В преданиях о кавказских амазонках говорится о предпочтении ими хромоногих мужчин: по словам их предводительницы, «хромой действует отлично» ${ }^{24}$. Фраза предводительницы - скрытый текст, основанный на представлении о связи хромоногости с хтоническими порождающими силами земли. Отсюда культ хромоногих или одноногих божеств, вроде адыгского Созереша. Кстати, культ его исполнял жрец, обычно хромоногий старик.

Так почему говорят, что «в ногах правды нет»? Это тоже скрытый текст. Конфликтный. Речение агрессивно направлено на ноги в пользу сидения. Это дает возможность вступить в дело рукам с их коммуникативной знаковостью. Ради разговора, общения. Социально-деловое соглашение завершается пожатием рук, возгласом «По рукам!».

\footnotetext{
${ }^{23}$ Юнг К.-Г. Либидо, его метаморфозы и символы. М., 1994. C. $110-111$.

24 Латышев В. Известия древних писателей о Скифии и Кавказе // Вестник древней истории. 1948. № 3. С. 291.
} 


\section{Философия и культура 5(65) • 2013}

\section{6. Великаны и титаны}

Хтонически земная тема скрыта в мировом эпосе. Образы великанов ассоциированы с землей. И земля, которая продавливается под ногами Микулы Селяниновича (в русском варианте), маркирует его гигантизм. В грузинском эпосе великан стал «одноногим» после того, как Богоборец Амирани ему подрезал сухожилия ног ${ }^{25}$.

Сказочные и эпические великаны - родные братья титанов древнегреческих философскоэпических мифов. Вот Атлант, черпающий силу в прикосновении к матери-земле. Это узнал Геракл, который оторвал титана от земли и его победил. Сизиф наказан вечно катить в гору камень - это хтоническое наказание за его путешествие в потусторонний мир. В этом же аспекте нужно понимать и хромоту бога Гефеста, кузница которого расположена под землей.

Практически в любом эпосе мышление осмысливает проблему гигантизма, делая из неё то философское эссе о сражении Дон Кихота с ветряными мельницами, то сатиру Джонатана Свифта о приключениях Гулливера, а то загадочный юмор Франсуа Рабле, смысл которого нам раскрыл М. М Бахтин.

Титанизм - геоментальная философия человечества. Так можно воспринять смысл учения Я.Э. Голосовкера о титанах. Его «Сказания о титанах» и «Сказание о кентавре Хироне», в сущности, прочтение скрытых текстов в свете «имагинативного абсолюта», принцип которого он выдвинул для обоснования права исследователя ревизовать привычную олимпийскую мифологию и восстановить титанический этап в жизни идей ${ }^{26}$. А что было в реальной жизни? Был праздник и балаган. Если со смыслами праздника мы примирились не в последнюю очередь благодаря усилиямученых, его изучавших, то сбалаганом ещене так. Но тут есть такие энтузиасты и проницательные умы, как И.П. Уварова, собравшая вокруг себя других исследователей.

«Культура родилась в балагане», - говорит Ирина Павловна ${ }^{27}$. Развивая это открытие, я в главе «Балаган помнит о титанизме человека» книги о телесности, установил следующее ${ }^{28}$.

- Культура всегда театральна и перформативна.

25 Сборник материалов для описания местностей Кавказа. Вып. 32. Отд. II. Тифлис, 1903. С. 163.

26 Голосовкер Я.Э. Логика мифа. М.: Наука, 1987.

27 Уварова И.П. Балаган. Часть 1. М., 2002. С. 6.

28 Чеснов Я.В. Телесность человека: философско-антропологическое понимание. М.: ИФ РАН, 2007. Гл. 4.
- Человек способен увидеть чудо (например, pyсалку), если войдет в соответствующее состояние сознания (порог религии, по Р. Маретту).

- Балаган и клоунада получены нами от людей, титанически относившихся к миру Суть этого отношения в непоглощенности человека социумом, в нахождении человека в континууме свободы, которая берет истоки в хтонически земном начале у титанов и в «пещерном» прошлом человечества.

Титаническое начало в человеке связано с его телесной субстанцией. Она состоит из земли, как у Атланта, символизирована камнем у Сизифа, заключена в пепле сожженных титанов, из которого у греков снова возник Дионис. Земное минеральное начало дано ветхозаветному Адаму, сотворенному из глины. Эта же петроментальность направила мышление австралийских аборигенов, считающих, что для здоровья человека знахарь в его тело должен ввести кусок кварца. В таком случае, их знахарь манипулятор баланса между минеральной средой и мягкими тканями человека. У белых людей, по их мнению, в теле слишком много соли и поэтому аборигенное колдовство на белых не действует.

Итак, титаническое тело включает земную (минеральную) субстанцию. Оно принципиально не выделено из природы. Можно сказать, что у человека оно в силу петроментальности не до конца человеческое. В этом скрытый текст титанического тела. Оно еще бывает организовано фитоментально и зооментально, об этом мы сейчас не говорим. Самое фундаментальное тело воспринимается в народных культурах все-таки петроментально.

Выше мы анализировали абхазское представление о следах как потомстве человека. Теперь следы можно проинтерпретировать как скрытый текст, говорящий о титанической земной природе человека и его потомства.

\section{7. Тело и ландиафт}

Во многих языках народов мира органы тела служат метафорическими обозначения элементов физического ландшафта: «голова» - это вершина, «подножие» - ее основание, «рука», «рукав» русло реки, «голова» канала (кстати, это вовсе не его начало, а конец) и т.д.

В специальной литературе часто обращается внимание на мифологему первотела, где части Вселенной возникли из его органов (вроде Пуруши в индийском эпосе, Адама Кадмона в еврейской натурфилософии). 


\section{Герменевтика}

Эти образы моделируют Вселенную уже готовой плотью человека. А вот образы первосуществ у австралийских аборигенов еще не утратили своей минерально-земной природы. Они в виде первопредков бродили по австралийскому континенту. От них остались следы в виде элементов ландшафта. В конце концов, эти предки ушли под землю, вернулись в хтонические недра. Там, где это случилось, остались водоемы.

Не все культуры так явно превращают ландшафт из среды обитания в элемент жизнедеятельности как в абхазской культуре, т.е. онтологизируют его до собственного автообраза ${ }^{29}$. Всепроникающая черта традиционного абхазского восприятия мира, то, что витальность составляет аспект практически любого, большого и малого, элемента ландшафтной среды. Поэтому в данном случае нужно говорить именно об аспектах, но не о классах единого природно-человеческого образования.

Повсюду есть опасные и добрые места, грецкий орех около дома не сажают - опасен, как и хвойные породы, - они слишком «гордые» по отношению к человеку. Благоприятен дом, построенный из каштановых досок. А вот скамью делают из ольхи изделие из этого мягкого «не гордого» дерева не переживет срока жизни человека. Да и сидя на ней, человек наполняется силой. Заметим, срок жизни человека соотнесен с растениями.

Есть плохая и хорошая вода. Так, под свесом крыши стоять нельзя, особенно, детям: их здоровью могут повредить черти. Люди раньше не знали, что у текущей воды бывает вредный поток, сменяемый затем полезным, откуда надо брать питьевую воду. Это в одной семье жила русалка дзыдзлан и научила столь важным сведениям.

Всеобщая благодать сосредоточена в горах с центром в районе Псху. Она спускается на равнины, их облагораживая. За исключением, однако, устья Ингури (алада цигя - дурной юго-восток): оттуда идут неблагоприятные климатические явления.

В философско-антропологической парадигме ландшафт высокого статуса принято называть сакральным. Но в перечисленных верованиях и навыках (упомянем, кстати, запрет садиться на голую землю: в горах мой товарищ, сообщив мне это, сам сел на свой снятый ботинок) сакральность зачастую отсутствует. Но имеет место нормированное вплоть

29 Чеснов Я.В. Ландшафт - внутренняя телесность долгожительской культуры абхазов // Философские науки. 2003. № 8. C. $75-83$. до табуированности отношений человека и объекта. Запретительное отношение к чему-либо по-абхазски выражается словом цасым (нельзя, не положено в приближенной к русскому графике). Сфера цасым касается этикетных сторон не только внутри человеческого общества, но охватывает весь доступный человеку ландшафт: этикетное отношение к воде, огню, животному, которого «нельзя обидеть». Взять из ландшафта лишний ресурс (хотя бы дрова) - цасым. Особый и строгий спектр правил нормирует ситуации выделений организма.

Ю.И. Семенов справедливо специфику отношений, когда они не являются ни правом и ни моралью, назвал табуитетом ${ }^{30}$. Это отношения воления. Заметим, что табуитет конституирует вовсе не недостаток средств, но структурирует их использование в условиях избыточности. Причем табуитет ничему не дает предпочтения - это равное отношение к вещам.

Но нарушение ценностно-волевого отношения к среде (цасыма/табуитета) влечет заболевание человека и даже смерть, но эти бедствия могут и не коснуться его, зато в тяжелых нарушениях следует заболевание потомков или всего рода.

Получается, что нравственная по местным понятиям жизнь может длиться неограниченно долго и ей конец может положить не этикетное отношение к ландшафту и его составляющим: к воде и огню, к фауне и флоре. Это не мешает компонентам ландшафта быть активно включеными в традиционный хозяйственный цикл сельской общины.

Тип такого адаптивного отношения мной было предложено называть культуроценозом ${ }^{31}$. В его пределах человек включается в природу. Но есть другой ценоз, о котором пойдет речь ниже. Обычно более узкий, когда человек включает природу в состав своей жизнедеятельности, а также использует часть природы как знак собственной самоидентификации - антропоценоз $3^{32}$. В старину в Абхазии знаком такой идентификации было, например, держание отличной породы лошадей и уменье гарцевать, а также другие личные особенности. Обширная поляна перед домом предназначалась для гостя, чтобы он «оставил на ней следы» своего наезднического умения. Запасение здоровьем путем купания в определенные дни - распространено

\footnotetext{
30 Семенов Ю.И. Форма общественной воли в доклассовом обществе: табуитет, мораль и обычное право // Этнографическое обозрение. 1997. № 3. С. 3-24.

31 Чеснов Я.В. Лекции по исторической этнологии. М., 1998.

32 См.: там же.
} 


\section{Философия и культура 5(65) • 2013}

повсюду. Но у абхазо-адыгских народов это надо сделать непременно раньше любого зверя. Здесь последний становится частью человеческого антропоценоза. Антропоценоз каждого члена общества в совокупности пассионарно расширяется до территории всей страны, до всего ландшафта и мотиваций обустройства в нем. Ландшафт становится фактором человеческой телесности.

\section{8. Титаническое отночение к ландиафту у долгожителей}

В связи с последним утверждением придется рассмотреть известный у антропологов Кавказа, но не в широкой научной общественности обычай «поминок по живому». Правда, они плохо описаны. Упоминаются главным образом в обычаях горцев в XIX в., например, у хевсур - горных грузин, близких по культуре к горным чеченцам. По известным мне описаниям, пожилой человек, чтобы о себе оставить память, делал персонально значимое общественное дело: обустраивал родник, оборудовал стоянку для путников, а то строил даже мост. В честь события устраивали стол, за которым говорили о живом, как о мертвом, отмечая его добрые дела. Меня этот обычай чрезвычайно интересовал, но получалось, что это память о каком-то очень уж отдаленном прошлом. И вдруг в конце октября 1987 г. состоялись эти самые поминки, посвященные не кому-то либо, а моему старшему другу, лет 60-ти, Урычу Смыру из села Аацы, в доме которого я часто останавливался. «Поминки», правда, никто уже не произносил, для таких случаев давно уже использовали русское слово «компания». Суть дела была в том, что Урыч работал на хлопотной должности заведующего животноводческой фермой. На летние пастбища крупный рогатый и мелкий скот из приморского села Аацы приходилось везти на грузовиках в район озера Рица. А далее скот сгружали и гнали выше в горы к водному источнику Ауатхара. Года три Урыч, когда один, когда с сыновьями расчищал путь на пастбище.

В результате этот трудный подъем сократился с 15 километров до 3-х. В народе новый участок стали называть «Путем Урыча», но как бы неофициально. Через год Урыч устроил за свой счет обильное угощение. От более старших земляков Урыча были тосты в его честь. Никто не чокался. И сам он не пил и все время стоял, позволив себе сесть только в самом конце застолья, и то занял место с самого краю скамьи.

Охотник, уходящий надолго в горы, принадлежит не жене, не людям, а мистически поступает в распоряжение богини охоты, взамен получая дичь. С кем мог идентифицировать себя человек, сам по себе устроивший веселую «компанию» с элементами плача? С вечным родовым телом своего этноса, получая в этом официальное признание, свою этническую идентичность. Теперь из жизни его могли бы выбить только чрезвычайные обстоятельства. Поэтому правы те исследователи, которые в долгожительстве видят не семейно-генетическую, а популяционную линию.

Посмотрим с самых общих позиций на жизнь абхазских долгожителей. Все они различаются характерами и пристрастиями. Кто-то никогда не курил, другой дымит на тебя своим самосадом. Ктото избегает есть зелень (вспомним миф об отнесении ее к нечистому началу). Есть несколько пчеловодов, практически живущие в горах со своими серыми злыми пчелами кавказянками. Мечты большинства - построить на усадьбе для себя маленький домик апацху с плетеными стенами и согреваемую только костром. У круглого столика там всегда есть место для гостя.

Там он может услышать прекрасные и мудрые слова о том, «что время, проведенное за столом, в срок жизни не включается». В большой винный сосуд для вина ахапща, который закопан в землю, помещается 365 столовых кувшинов вина. Об одной старушке сохранилась память, что она в 1930-е гт. сказала, что выйдет только за такого парня, который назовет 365 несъедобных частей в бычьей туше. Как видим, онтологизационному сгущению подвергается даже время. Сам долгожитель и есть носитель сгущенного через ландшафт благодатного времени.

Общее наше резюме в отношении абхазской долгожительской культуры:

- Здесь природа не столько фактор или среда, сколько модальность состояния человека, часть его жизнедеятельности;

- Несмотря на разницу в здоровье среди носителей данной культуры, они все онтологически разделяют постулат коллективного здоровья и этос долгожительства;

- В таких условиях каждый индивид может формировать время своего долгожительства;

- Долгожительство становится капиталом, хранимым всей популяцией, а ландшафт выступает порождающим и транслирующим средством.

\section{9. Основной миф у индоевропейцеев}

В.В. Иванов и В.И. Топоров предложили оригинальную версию толкования мифа о борьбе бога грозы со своим противником: они назвали его ос- 
новным мифом индоевропейцев. Но после публикации их исследования этот миф был обнаружен у народов других языковых семей. В ветхозаветной «Книге пророка Даниила» речь идет о колоссе царя, которого смогли уничтожить только камнем, поднятым с горы без помощи рук. Этот камень перебил глиняную и железную ноги поверженного колосса. Обратим внимание, что здесь речь идет не об оппозиции ног и рук, а все о той же хтонической борьбе смыслов внутри первоначального хаоса.

А теперь расскажем поподробнее об удивительном каменном существе гиганте Улликумми ${ }^{33}$. О нем рассказывается в хеттском мифе. Напомним, что хетты говорили на индоевропейском языке. B III-II тысячелетиях они населяли центр Малой Азии, куда двумя тысячелетиями ранее переселились из Балкан. Следы их влияния обнаруживают среди современных народов Балкан, Ближнего Востока и Кавказа. Эти следы - знаки скрытых этнокультурных текстов.

В мифе речь идет о соперничестве поколений отцов и детей. Относящийся к младшему поколению бог Кумарди от богини земли рождает сына Улликумми. Он отправляет его в подземное царство, там его поместили на плечо гиганта Убеллури - гиганта, который держит на себе весь мир. Улликумми стал расти и достиг небес. Его испугались боги и люди. Боги борются с Улликумми с помощью старого медного ножа, которым небо было отделено от земли. Им подсекают ноги колосса. В конце концов, бог Бури побеждает Улликумми.

Внутренняя драма борьбы между хтонизмом ног и небесными силами (бури и грома) - один из основных архетипов всего человечества. Это поразительно. На полуострове Малакка в тени мрачных тропических лесов бродят маленькие группы пигмеев сеноев и семангов. Они занимаются охотой и собирательством. Когда над лесами сгущаются тучи и раздается гром, люди из этих племен в панике. У семангов бог грома «Карей обитает в пещере и олицетворяет гром как природное явление. Он выступает как грозное и злое божество. Его особенно боятся женщины. Для умилостивления Карея при громе семанги пускали свою кровь из раны, нанесенной в икру ноги» 34 .

Вот вам местная версия мифа об Уликкумми, созданного у совсем других народов. Обратим внимание на то, что женщины у семангов при громе

\footnotetext{
33 Песнь об Улликумми // Луна, упавшая с неба. М., 1977.

34 Чеснов Я.В. Мон-кхмерские народы // Мифы и религии мира: учеб. пособие. М., 2004. С. 182-186.
}

имитируют ежемесячные кровотечения. Здесь ноги отнесены к хтоническому родильному началу. Мировоззренческая система уже замкнулась и на небесный уровень. В сущности то же самое делали древние китайцы, когда они для вызывания дождя и грома со всей силой стучали в барабаны. Прорыв кожаной мембраны на барабане знаменовал дефлорацию женщины. Теперь нам должно быть понятно старинное на Руси охальное свадебное пожелание молодоженам «Чтоб ... стоял и дети грома не боялись». Человечество, однако, едино: хетты, семанги, китайцы и русские.

Выше шла речь о статуарности личного мифа со сноской на творчество А.С. Пушкина. Статуарность архетипически восходит к петроментальности. Каменные Улликумми индоевропейцев и другие подобные образы говорят о пробуждении личности в виде героя-богоборца против сонмища языческих богов. Но ведь и каменное орудие доисторического человека тоже личностно. Петроментальность основа титанической сущности человека.

Тогда, действительно, оказывается, что тяга к монотеизму характеризовала всю историю людей. Вот и подтверждение приведенного выше определения культуры П.С. Гуревичем, где говорится о сакральном источнике культуры.

\section{1о. Изъяны балагана и культурогенез}

Значит, титанические существа, имеющие отношение к хтоносу, хромоноги и одноноги. Ритуальное воспроизведение хтонизма демонстрируют первобытные семанги, то же делали, согласно легендам, амазонки. Короче, титанизм маркируется неким физическим изъяном. Сейчас мы можем поставить вопрос о том, что если феномен долгожительства имеет титаническую природу, то каким физическим изъяном должны отличаться долгожители? Ответить на него просто невозможно. Нужно снова обращаться к герменевтике скрытых текстов.

Сначала обратимся к образу титана-богоборца к Прометею. Он, прикованный к скале Кавказа (его способ акцентирования петроментальности), ежедневно теряет печень, выклевываемую орлом. Это маркер его физического изъяна, его титанизма. К разряду подобных титанов мы можем отнести библейского Иакова, который ночью боролся с ангелом и получил повреждение бедра. Можно назвать многих хромоногих эпических героев, имеющих отношение к титанизму. Здесь и древнегреческий Эдип (буквально «распухшая нога») и Илья Муромец русских былин, с детства болевший ногами. 


\section{Философия и культура 5(65) • 2013}

У всех перечисленных персонажей их деяния и подвиги проистекают из их титанической сущности, имеющей свой моноисток в хтоническом мире. Эта сущность не-коммуникативна, но эссенциальна.

Из рассмотрения судеб названных персонажей можно выделить следующее. Творческое начало в человеке не коммуникативно. Оно является следствием внутренних природных сил. Поэтому так трагична судьба творцов в нашем обществе.

И вот мы уже подходим ближе к нашей концепции феномена долгожительства. Мое общение не с одним десятком долгожителей Кавказа позволило обнаружить удивительную черту их психотипа. Она состоит в том, что эти люди, несмотря на самый преклонный возраст, были вне пассивных ролей, задаваемых социумом. Это были бунтари, в сущности, титаны. Они отстояли свой образ жизни. В том место, куда она их поставила. Подробно рассмотренную историю Урыча Смыр, по-видимому, можно с полным правом отнести к титаническому регистру. В его случае имела место реальная петроментальность - прокладывание горной дороги. Но в бытовых кавказских ситуациях, например, в деревенских соревнованиях парней по бросанию на дальность тяжелых камней, весом в пуда два, я вижу все тот же скрытый текст титанизма.

Остается сказать вот что. Мы опять оттолкнемся от эсхиловской истории о Прометее. Мучающийся на скале титан одолеваем странным желанием. Он хочет, чтобы его муки увидели люди. Он обращается к ним:
«Посмотрите» 35 . Поразительно и то, что библейский Авраам на зов Бога отвечает: «Увидь меня» («хинна ни» по-арамейски, в переводах «Вот я»).

Получается, что желание быть видимым относится к табло сознания титанического поведения. Тут мы подходим к титанической перфомативной теории происхождения театра. К этому полю сознания восходит теория театральности, уходящей корнями в природу у Н.Н. Евреинова. Анализ балагана, архаического театра подтверждает мысль о титанической сущности перфоманса. В балагане всех исследователей поражает непритязательность театральных средств, как будто нарочно выставлявших на показ зрителям свою «сделанность» и неприкрытую наивность. Зрители прекрасно знали, что Сирена - это девчонка, выставлявшая в дырку в полотне свою голову. Ниже головы были грубо намалеваны ее руки и торс, а в качестве хвоста к изображению была приделана задняя часть белуги.

«Сделанность» у персонажей балагана сродни титаническим изъянам. Значит, в балагане работает не обман, а демонстрация хтонической честности и потребность быть видимым. В балагане за его пестрым фенотекстом проглядывает генотекст сакральности. К титанической визуальной трансцендентности восходят знаки на стенах палеолитических пещер, а значит и письма. В принятой здесь терминологии к «тексту». Как видим, «открытость человеческой природы» обращена «на поиск сакрального смысла бытия».

\section{Список литературы:}

1. Бахтин М.М. К философии поступка // Философия и социология науки и техники. Ежегодник. 19841985. M., 1986.

2. Бахтин М.М. Эстетика словесного творчества. М., 1986.

3. Библер В.С. Сократ и Кратос. Энигма-диалог по пяти диалогам Платона [Электронный ресурс] // http://www.bibler.ru/bis_sokrat.html.

4. Библер В. С. Михаил Михайлович Бахтин, или Поэтика культуры. М., 1991.

5. Голосовкер Я. Э. Логика мифа. М.: Наука, 1987.

6. Латышев В. Известия древних писателей о Скифии и Кавказе // Вестник древней истории. 1948. № 3.

7. Леви-Строс К. Структура мифов // Вопросы философии. 1970. № 7.

8. Песнь об Улликумми // Луна, упавшая с неба. М., 1977.

9. Сборник материалов для описания местностей Кавказа. Вып. 32. Отд. II. Тифлис, 1903. С. 163.

10. Семенов Ю.И. Форма общественной воли в доклассовом обществе: табуитет, мораль и обычное право // Этнографическое обозрение. 1997. № 3.

11. Тищенко П. Библер Владимир Соломонович [Электронный ресурс] // http://encyclopaedia.biga.ru/ enc/liberal_arts/BIBLER_VLADIMIR_SOLOMONOVICH.html.

12. Уварова И.П. Балаган. Часть 1. М., 2002.

\footnotetext{
35 Чеснов Я.В. Телесность человека: философско-антропологическое понимание. М.: ИФ РАН, 2007.
} 


\section{Герменевтика}

13. Фрейд 3. По ту сторону принципа наслаждений. Я и Оно // Фрейд З. Избранные труды. Л., 1969. Т. 1.

14. Чеснов Я.В. Мон-кхмерские народы // Мифы и религии мира: Учебное пособие. М., 2004. С. 182-186.

15. Чеснов Я.В. Лекции по исторической этнологии. М.: Гардарика. 1998.

16. Чеснов Я.В. Телесность человека: философско-антропологическое понимание. М.: ИФ РАН, 2007.

17. Чеснов Я.В. Ландшафт - внутренняя телесность долгожительской культуры абхазов // Философские науки. 2003. № 8. С. 75-83.

18. Чулков М. Абевегеда русских суеверий. М., 1776.

19. Шаумян С.К. Аппликативная порождающая модель // Словари и энциклопедии на Академике [Электронный ресурс] // http://enc-dic.com/enc_sovet/Applikativnaja-porozhdajuschaja-model-69903.html.

20. Юнг К.-Г. Либидо, его метаморфозы и символы. М., 1994.

21. Kristeva J. Séméiôtiké: recherches pour une sémanalyse, P.: Edition du Seuil, 1969. (Английский перевод Desire in Language: A Semiotic Approach to Literature and Art. Oxford: Blackwell, 1980).

22. Kristeva J. La Révolution du langage Poétique: L'avant-garde a la fin du XIXe siècle, Lautréamont et Mallarmé. Paris: Éditions du Seuil, 1974. (Английский перевод - Revolution in Poetic Language, New York: Columbia University Press, 1984).

23. Szekeley M.D. Gesture, Pulsion, Grain: Bartes' Musical Semiology [Электронный pecypc] // // http:// www.contempaesthetics.org/newvolume/pages/article.php?articleID=409.

\section{References (transliteration):}

1. Bakhtin M.M. K filosofii postupka // Filosofiya i sotsiologiya nauki i tekhniki. Ezhegodnik. 1984-1985. M., 1986.

2. Bakhtin M.M. Estetika slovesnogo tvorchestva. M., 1986.

3. Bibler V.S. Sokrat i Kratos. Enigma-dialog po pyati dialogam Platona [Elektronyy resurs] // http://www. bibler.ru/bis_sokrat.html.

4. Bibler V.S. Mikhail Mikhaylovich Bakhtin, ili Poetika kul'tury. M., 1991.

5. Golosovker Ya. E. Logika mifa. M.: Nauka, 1987.

6. Latyshev V. Izvestiya drevnikh pisateley o Skifii i Kavkaze // Vestnik drevney istorii. 1948. № 3.

7. Levi-Stros K. Struktura mifov // Voprosy filosofii. 1970. № 7.

8. Pesn' ob Ullikummi // Luna, upavshaya s neba. M., 1977.

9. Sbornik materialov dlya opisaniya mestnostey Kavkaza. Vyp. 32. Otd. II. Tiflis, 1903. S. 163.

10. Semenov Yu.I. Forma obshchestvennoy voli v doklassovom obshchestve: tabuitet, moral' i obychnoe pravo // Etnograficheskoe obozrenie. 1997. № 3 .

11. Tishchenko P. Bibler Vladimir Solomonovich [Elektronyy resurs] // http://encyclopaedia.biga.ru/enc/ liberal_arts/BIBLER_VLADIMIR_SOLOMONOVICH.html.

12. Uvarova I.P. Balagan. Chast' 1. M., 2002.

13. Freyd Z. Po tu storonu printsipa naslazhdeniy. Ya i Ono // Freyd Z. Izbrannye trudy. L., 1969. T. 1.

14. Chesnov Ya.V. Mon-kkhmerskie narody // Mify i religii mira. Uchebnoe posobie. M., 2004. S. 182-186.

15. Chesnov Ya.V. Lektsii po istoricheskoy etnologii. M.: Gardarika. 1998.

16. Chesnov Ya.V. Telesnost' cheloveka: filosofsko-antropologicheskoe ponimanie. M.: IF RAN, 2007.

17. Chesnov Ya.V. Landshaft - vnutrennyaya telesnost' dolgozhitel'skoy kul'tury abkhazov // Filosofskie nauki. 2003. № 8. S. 75-83.

18. Chulkov M. Abevegeda russkikh sueveriy. M., 1776.

19. Shaumyan S.K. Applikativnaya porozhdayushchaya model' // Slovari i entsiklopedii na Akademike [Elektronyy resurs] // http://enc-dic.com/enc_sovet/Applikativnaja-porozhdajuschaja-model-69903.html.

20. Yung K.-G. Libido, ego metamorfozy i simvoly. M., 1994.

21. Kristeva J. Séméiôtiké: recherches pour une sémanalyse, P.: Edition du Seuil, 1969. (Английский перевод Desire in Language: A Semiotic Approach to Literature and Art. Oxford: Blackwell, 1980.)

22. Kristeva J. La Révolution du langage Poétique: L'avant-garde a la fin du XIXe siècle, Lautréamont et Mallarmé. Paris: Éditions du Seuil, 1974. (Английский перевод - Revolution in Poetic Language, New York: Columbia University Press, 1984).

23. Szekeley M.D. Gesture, Pulsion, Grain: Bartes' Musical Semiology [Elektronyy resurs] // http://www. contempaesthetics.org/newvolume/pages/article.php?articleID=409. 